\title{
KEDUDUKAN BANK ASING DALAM PERBANKAN INDONESIA DIHUBUNGKAN DENGAN UNDANG-UNDANG NOMOR 10 TAHUN 1998 TENTANG PERUBAHAN ATAS UNDANG-UNDANG NOMOR 7 TAHUN 1992 TENTANG PERBANKAN
}

\author{
${ }^{1}$ Waliyunisa, ${ }^{2}$ Neni Sri Imaniyati \\ Alumni Program Studi Magister Kenotariatan \\ Pascasarjana Universitas Islam Bandung \\ Email : Waliyunisa94@gmail.com \\ Imaniyati89@gmail.com
}

\begin{abstract}
Abstrak : Kedudukan bank Asing di Indonesia sama dengan bank umum nasional, yang ditegaskan dalam UU Perbankan Tahun 1992 dan dalam UU Perbankan yang baru Nomor 10 Tahun 1998. Dengan kedudukan yang sama antara bank Asing dan bank umum nasional tersebut, Bank Indonesia selaku pembina dan pengawas bank umum di Indonesia, serta memberi perlakuan yang sama pada bank Asing. Perlakuan yang sama tersebut meliputi penilaian tingkat kesehatan bank maupun peraturanperaturan Perbankan Nasional Indonesia. Tetapi Peraturan Perundang-undangan secara khusus yang mengatur tentang Bank Asing di Indonesia belum ada. Karena peraturan perundang-undangan di Indonesia belum secara jelas mengatur hubungan hukum antara Nasabah dan bank, maka perlindungan hukum bagi nasabah bank Asing khususnya bersifat tindakan preventif. Tujan penelitian ini untuk memahami kedudukan bank asing dalam perbankan Indonesia yang duhubungkan dengan UU Perbankan. Penelitian ini menggunakan metode yuridis normatif. Data yang digunakan data sekunder. Teknik Pengambilan data melalui studi kepustakaan. Hasil dari penelitian ini bahwa Kedudukan bank Asing dalam perbankan Indonesia adalah membantu misi pemerintah untuk mendorong pembangunan di Indonesia dalam rangka mencapai pertumbuhan, pemerataan dan stabilitas yang merupakan tujuan perbankan di Indonesia.
\end{abstract}

Kata Kunci : Hukum, Bank Asing, Kedudukan Bank

Abstract: The position of foreign banks in Indonesia is the same as national commercial banks confirmed in the Banking Law Year 1992 and in the new Banking Law Number 10 Year 1998. With the same position between the foreign bank and the national commercial bank, Bank Indonesia as a supervisor and controller of commercial banks in Indonesia, also treats foreign banks the same. This same treatment includes assessments of bank health level and the regulations of the Indonesian National Banking. However, there are no specific statutory regulations governing foreign banks in Indonesia. Since the laws and regulations in Indonesia have not clearly regulated yet the legal relationship between customers and banks, legal protection against foreign bank customers is particularly a preventive measure. Therefore, this study was conducted to understand the position of foreign banks in Indonesian banking related to the Banking Law. This study used a normative juridical method using secondary data through library study as its data collection technique. The result indicated that the position of foreign banks in Indonesian banking is to help 
${ }^{1}$ Waliyunisa, ${ }^{2}$ Neni Sri Imaniyati, Kedudukan Bank Asing Dalam Perbankan Indonesia...

the government to encourage development in Indonesia to achieve growth, equity, and stability, which are the objectives of banking in Indonesia.

Keywords : Law, Bank, Foreign, Position

\section{A. PENDAHULUAN}

Dalam masyarakat sederhana tidak adanya peran Bank dan lembaga keuangan, mungkin tidak terlalu menjadi masalah. Namun dalam masyarakat yang semakin berkembang saat ini, peran Bank dan lembaga keuangan lainnya sangatlah penting, khusunya sebagai lembagai mediasi antara pihak yang memiliki dana dan yang membutuhkan dana. Mekanisme aktivitas ekonomi masyarakat modern dengan peran bank dan lembaga keuangan lain. Secara umum dapat dikatakan, Bank dan lembaga keuangan menjadi pihak perantara bagi sektor rumah tangga dan sector industri, khususnya di dalam menyerap dana dari sektor rumah tangga dalam bentuk tabungan dan menyalurkannya kepada sektor industri sebagai kredit investasi. Meskipun dalam prakteknya penyerapan dan penyaluran dana itu sendiri dapat terjadi baik di dan untuk sektor rumah tangga maupun sektor industri.

Perkembangan perbankan menunjukkan dinamika dalam kehidupan ekonomi. Sebelum sampai pada praktik-praktik yang terjadi saat ini, ada banyak permasalahan yang terkait dengan masalah-masalah perbankan ini. Masalah utama yang muncul dalam praktik perbankan ini adalah pengaturan sistem keuangan yang berkaitan dengan mekanisme penentuan volume uang yang beredar dalam perekonomian. Sistem keuangan, yang terdiri dari otoritas keuangan (financial authorities), sistem perbankan dan sistem lembaga keuangan bukan bank, pada dasarnya merupakan tatanan dalam perekonomian suatu negara yang memiliki peran utama dalam menyediakan fasilitas jasa-jasa keuangan.

Bank asing yang bergerak di Indonesia adalah jelas bank umum. 
${ }^{1}$ Waliyunisa, ${ }^{2}$ Neni Sri Imaniyati, Kedudukan Bank Asing Dalam Perbankan Indonesia...

Kegiatan bank asing memilik tugas yang sama dengan bank umum, yang memberdakan kegiatannya adalah mereka lebih dikhususkan dalam bidang-bidang tertentu dan ada larangan tertentu dalam kegiatannya.

Adapun kegiatan bank asing di Indonesia adalah :

a. Dalam mencari dana bank asing juga membuka simpanan giro dan simpanan deposito namun dilarang menerima simpanan dalam bentuk tabungan.

b. Dalam hal pemberian kredit yang diberikan lebih diarahkan ke bidang-bidang tertentu saja seperti dalam bidang perdagangan internasional, bidang industry produksi dan penanaman modal asing.

Memilih bentuk hukum ideal bagi bank asing yang ingin melakukan kegiatan usaha di suatu negara tidak begitu mudah. Beragam pilihan tersedia seperti international banking facilities, kantor perwakilan (representative office), keagenan, kantor cabang atau perusahaan anak (subsidiary).

Pilihan tersebut mencerminkan tingkat kedalaman intervensi ke pasar negara penerima. Kantor perwakilan misalnya memiliki kewenangan terbatas, tidak boleh menerima simpanan, menyalurkan kredit atau melakukan transfer. Kantor cabang menawarkan jasa perbankan secara utuh dan kantor pusat bertanggung jawab atas kewajibannya. Perusahaan anak didirikan terpisah dari perusahaan induk. Perusahaan anak adalah badan hukum independen yang melakukan kegiatan perbankan secara lengkap dan beroperasi sebagai suatu perusahaan terpisah dari perusahaan induk namun dimiliki atau dikontrol oleh perusahaan induk.

Berdasarkan uraian yang telah dikemukakan dalam latar belakang diatas, maka dapat dirumuskan identifikasi masalah sebagai berikut:

(1) Bagaimanakah Peraturan Tentang Kedudukan Bank Asing di Indonesia dihubungkan dengan Undang-undang Undang 
${ }^{1}$ Waliyunisa, ${ }^{2}$ Neni Sri Imaniyati, Kedudukan Bank Asing Dalam Perbankan Indonesia...

Undang Nomor 10 Tahun 1998

Tentang Perbankan?

(2) Bagaimanakah pembatasan kepemilikan saham bank asing terhadap perbankan nasional di Indonesia?

\section{B. PEMBAHASAN}

\section{Tujuan Bank Asing}

Kehadiran bank asing dapat membawa manfaat kepada industri perbankan di negara penerima. Bank asing memfasilitasi akses negara penerima (host countries) terhadap produk dan teknologi baru dan meningkatkan efisiensi pasar keuangan dan kompetisi. Kehadiran bank asing di Indonesia dalam bentuk kantor cabang membawa permasalahan tersendiri. Selain risiko seperti yang di alami Eropa Tengah dan Timur yang lainnya dan lebih mikro adalah adalah kewajiban kantor cabang bank asing menjadi peserta Lembaga Penjamin Simpanan (LPS). Keikutsertaan kantor cabang bank asing menimbulkan masalah hukum apabila kantor pusat bank asing tersebut dicabut ijin usahanya dan kemudian dilikuidasi. Secara hukum kepailitan aset kantor cabang adalah bagian dari aset kantor pusat sehingga apabila kantor pusat bank dicabut ijin usahanya maka aset kantor cabang menjadi bagian dari aset likuidasi dan keseluruhan aset bank akan digunakan untuk membayar seluruh kewajiban bank tersebut. Sementara itu, kewajiban kantor cabang kepada nasabah simpanan sampai dengan batasan jumlah tertentu adalah kewajiban LPS. Dengan kondisi seperti ini potensi konflik hukum menjadi timbul. (Kasmir, 2012 :17).

Pertanyaan hukumnya adalah apakah kepentingan LPS harus didahulukan dibandingkan kepentingan kreditur lainnya dari kantor pusat bank yang bersangkutan. Pasal 59 UU LPS menetapkan bahwa LPS menguasai aset bank yang dilikuidasi dan hasil penjualan aset tersebut terlebih dahulu digunakan untuk pembayaran kepada LPS untuk mengembalikan dana LPS yang telah digunakan untuk membayar nasabah penyimpan. Berdasarkan UU kepentingan LPS harus didahulukan, alasannya adalah kantor cabang bank tersebut beroperasi di 
${ }^{1}$ Waliyunisa, ${ }^{2}$ Neni Sri Imaniyati, Kedudukan Bank Asing Dalam Perbankan Indonesia...

Indonesia sehingga tunduk kepada hukum Indonesia. Dalam perjanjian keikutsertaan sebagai anggota LPS secara tegas harus dicantumkan persyaratan bahwa aset kantor cabang bank asing harus terlebih dahulu digunakan untuk membayar kewajibannya di Indonesia. Kebangkrutan lintas negara merupakan masalah pelik dan membutuhkan aturan yang juga bersifat lintas negara. Akan tetapi sulit membayangkan kehadiran aturan likuidasi yang berlaku secara internasional. Oleh karena itu ada pemikiran agar bentuk hukum kantor cabang asing diubah menjadi badan hukum Indonesia dalam bentuk perusahaan anak.

Bank dalam bentuk perusahaan anak (subsidiaries) memiliki karakter dan permasalahan tersendiri. Perusahaan induk bank cenderung melakukan sentralisasi seluruh keputusan strategis dan manajemen risiko di kantor pusat. Perusahaan induk membatasi tanggung jawab hukumnya sebesar modal yang ditanamkan pada perusahaan anak. Badan pengawas di negara asal lebih banyak terlibat dalam penyusunan model-model risiko dan memperoleh lebih banyak informasi tentang kondisi perusahaan induk tetapi tidak bertanggung jawab atas potensi kegagalan perusahaan anak. Konsekuensinya negara penerima memikul tanggung jawab akhir dalam menyediakan bantuan likuiditas darurat dan mengumpulkan sisa-sisa asset bila terjadi krisis. Negara penerimajuga pihak yang wajib menjaga stabilitas keuangan dan memproteksi pembayar pajak yaitu pihak yang akhirnya menanggung biaya apabila ada bank yang bangkrut. Perusahaan induk sebagai pemilik bank secara hukum berhak mewajibkan perusahaan anaknya agar mematuhi setiap strategi bisnis yang mereka anggap tepat untuk memaksimalkan keuntungan. Padahal diantara strategi bisnis tersebut mungkin ada yang tidak sejalan dengan kepentingan perusahaan anak.

Akses pasar yang terbuka memerlukan rambu-rambu pengaman dan peningkatan kersama antar negara. Kehadiran pihak asing memang dibutuhkan tetapi bukan untuk solusi jangka pendek (short 
term medicine) dan menimbulkan implikasi negatif dalam jangka panjang baik bagi individual bank maupun sistem perbankan nasional. Peningkatan kerjasama dengan otoritas pengawasan bank negara lain merupakan salah satu opsi untuk mengatasi risiko kehadiran asing di sektor perbankan. Kerjasama internasional penting karena "bank adalah makluk global bila hidup, akan tetapi sangat nasionalis bila mati".

\section{Pengertian dan Peraturan} Tentang Kedudukan Bank Asing di Indonesia

\subsection{Pengertian Bank Asing}

Bank Asing Adalah bank-bank umum swasta yang merupakan perwakilan (kantor cabang) bankbank induknya di negara asalnya. Pada awalnya, bank-bank asing hanya boleh beroperasi di DKI Jakarta saja. Namun setelah dikeluarkan Pakto 27, 1988, bankbank asing ini diperkenankan untuk membuka kantor cabang pembantu di delapan kota, yaitu Jakarta, Surabaya, Semarang, Bandung, Denpasar, Ujung Pandang (Makasar), Medan, dan Batam. Bank-bank asing ini menjalaskan fungsi sebagaimana layaknya bank-bank umum swasta nasional, dan mereka tunduk pula pada ketentuan-ketentuan yang ditetapkan oleh Bank Indonesia.Kepemilikannya 100\% dimiliki oleh pihak asing (luar negeri).

Bank asing yang merupakan cabang bank asing yang berpusat di indonesia. Tugas dan fungsinya telah ditentukan secara tegas di dalam pemberian izinnya oleh menteri keuangan dan bank swasta asing ini hanya berada dikota-kota besar saja. Untuk mengkoordinasikan kehidupan perbankan di indonesia antara lain di dalam menyediakan dana uang untuk operasi dan mengatur serta mengelola peredaran uang di masyarakat, diperlukan suatu bank khusus yang disebut bank sirkulasi atau bank sentral.

Di indonesia bank tersebut adalah bank indonesia, bank ini berhak mencetak uang dan mengatur peredarannya sesuai kebijakan pemerintah di bidang keuangan. Di dalam kegiatannya, bank dapat menjamin seseorang dalam kegiatan usahanya artinya apabila nasabah 
${ }^{1}$ Waliyunisa, ${ }^{2}$ Neni Sri Imaniyati, Kedudukan Bank Asing Dalam Perbankan Indonesia...

berutang dan tidak dapat melunasinya bank dapat melakukan pembayaran utang nasabahnya itu.

Jaminan semacam ini disebut garansi bank nasabah harus memberikan barang (jaminan) tertentu.Umumnya, bank menyelenggarakan segala kegiatannya yang lazim berkaitan dengan masalah perbankan, dan bank semacam itu disebut bank umum. Disamping itu mungkin suatu bank hanya mengkhususkan pada kegiatan keuangan tertentu. Bank-bank asing dan bank campuran yang bergerak di Indonesia adalah jelas bank umum. Kegiatan bank asing dan bank campuran, memiliki tugasnya sama dengan bank umum lainnya. Yang membedakan kegiatannya dengan bank umum milik Indonesia adalah mereka lebih dikhususkan dalam bidang-bidang tertentu dan ada larangan tertentu pula dalam melakukan kegiatannya. (Hasibuan, Malayu S.P, 2005 :26).

Perbedaan utama antara bank asing dan bank campuran adalah pada bentuk hukumnya. Bank asing tetap berbadan hukum mengikuti kantor pusatnya di luar negeri dan merupakan bagian penting dari organisasi kantor pusatnya. Konsekuensinya, segala kebijakan keuangan bank asing amat tergantung dari kantor pusatnya, dan pada umumnya penyaluran kredit diberikan kepada perusahaanperusahaan besar seperti juga yang terjadi pada bank asing di Indonesia yang penyaluran kreditnya. (Henry, Tan. ANALISIS PERBEDAAN KINERJA KEUANGAN ANTARA BANK ASING DAN BANK UMUM DI INDONESIA. Magister Manajemen / Perbankan. Universitas Gunadarma, Indonesia).

Cenderung pada perusahaan multinasional yang juga mendapat pembiayaan dari kantor pusatnya. Sementara itu, bank campuran berbadan hukum lokal, di Indonesia berbentuk Perseroan Terbatas atau PT, dan secara hukum merupakan entity yang terpisah dari kantor induknya. Pada dasarnya kebijakan dan pengaturan oleh Bank Indonesia terhadap bank asing dan bank campuran bersifat equal. Seluruh ketentuan yang berlaku, termasuk ketentuan kehati-hatian, diterapkan secara seragam untuk seluruh bank 
${ }^{1}$ Waliyunisa, ${ }^{2}$ Neni Sri Imaniyati, Kedudukan Bank Asing Dalam Perbankan Indonesia...

yang beroperasi di Indonesia, baik bank domestik, bank campuran maupun bank asing. Perbedaan pengaturan terdapat pada modal.

Untuk bank dengan badan hukum Indonesia, mengikuti undang-undang PT, dan modal usaha tercatat pada neraca bank sebagai modal disetor, sedangkan untuk bank asing dengan badan hukum mengikuti kantor pusatnya, maka modal usaha tercatat pada neraca sebagai antar kantor dan disebut sebagai dana usaha. Pembatasan yang diterapkan terhadap bank asing berupa pembatasan secara geografis dalam membuka kantor, yaitu hanya diperbolehkan pada ibukota propinsi.

\subsection{Kedudukan Bank Asing}

Undang-Undang Nomor 10 Tahun 1998 tentang perbankan tidak memberikan banyak pilihan mengenai bentuk hukum keberadaan bank asing. Pihak asing yang ingin melakukan kegiatan usaha di sektor perbankan hanya dapat melakukannya melalui tiga cara yaitu pembukaan kantor cabang, pendirian bank baru dan membeli saham bank yang telah berdiri, langsung atau melalui bursa efek. Untuk pembukaan kantor cabang dipersyaratkan bank yang memiliki peringkat dan reputasi yang baik. Total asset yang dimiliki bank asing yang ingin membuka kantor cabang tersebut harus termasuk dalam dua ratus besar dunia dan wajib menempatkan dana usaha dalam valuta rupiah atau valuta asing sekurang-kurangnya Rp. 3.000.000.000.000,- $\quad$ Sedangkan pembukaan perusahaan anak hanya dapat dilakukan dengan bermitra dengan perorangan atau badan hukum domestik. Peraturan perundang-undangan di bidang perbankan tidak mengenal perusahaan anak yang sepenuhnya dimiliki oleh asing (wholly owned subsidiary).

Keberadaan kantor cabang bank asing di Indonesia telah melalui proses sejarah yang panjang. Di awal Orde Baru, Presidium Kabinet Ampera mengintruksikan Menteri Keuangan dan Gubernur Bank Sentral untuk memberikan izin usaha kepada beberapa bank asing untuk beroperasi di Indonesia. Dalam Instruksi tersebut jumlah bank asing dibatasi berdasarkan azas resiprositas 
${ }^{1}$ Waliyunisa, ${ }^{2}$ Neni Sri Imaniyati, Kedudukan Bank Asing Dalam Perbankan Indonesia...

serta peranan negara asal bank asing yang bersangkutan sebagai sumber penanaman modal asing dan atau sumber bantuan ekonomi. Alasan dibolehkannya bank asing beroparasi di Indonesia pada waktu itu, agar bank asing dapat ikut serta memperlancar masuknya investasi asing dan penyelenggaraan impor/ekspor di Indonesia, pengembangan industri dan produksi dalam negeri serta perluasan kesempatan kerja dan peningkatan produktivitas bagi potensi-potensi nasional. Menteri Negara Ekonomi pada 20 Februari 1968 menyatakan agar semua instansi pemerintah, para usahawan dan niagawan menunjukkan sikap positif terhadap kehadiran bank asing. Dalam sikap positif tersebut termasuk pula sikap untuk menghindari dan mengelakkan kebijakan dan peraturan yang simpang siur dan tidak menjamin kepastian kerja bagi bank asing serta menyalahi azas-azas perbankan yang lazim. Pembatasan-pembatasan secara apriori seperti dalam soal giro, deposito, dan perkreditan akan mempersempit kegiatan bank asing sehingga tidak memadai dibanding dengan risiko yang mereka hadapi dalam beroperasi di Indonesia.

Instruksi Presidum Kabinet

tersebut direalisasikan dengan terbitnya Undang-Undang Nomor 14 Tahun 1967 Tentang Perbankan dan Peraturan Pemerintah Nomor 3 Tahun 1968 tentang Bank Asing. Dalam Peraturan Pemerintah tersebut antara lain ditetapkan bahwa bank asing yang berusaha dalam bidang bank umum hanya dapat didirikan dalam bentuk kantor cabang dari bank yang sudah ada di luar negeri atau merupakan bank campuran antara bank asing dan bank nasional yang berbadan hukum Indonesia, dan bank campuran tersebut harus berbentuk perseroan terbatas. Berdasarkan Peraturan Pemerintah tersebut 11 bank asing mendapatkan izin untuk berusaha di Indonesia yang terdiri dari 10 kantor cabang bank yang berkedudukan di luar negeri dan satu bank campuran. Sepuluh kantor cabang bank asing tersebut adalah National City Bank of New York yang berubah menjadi Citibank, Bank of America, Chase Manhattan Bank, American Express Bank, The Chartered Bank yang 
${ }^{1}$ Waliyunisa, ${ }^{2}$ Neni Sri Imaniyati, Kedudukan Bank Asing Dalam Perbankan Indonesia...

kemudian menjadi Standard Chartered, Algemene Bank Nederland yang kemudian menjadi ABN-Amro, Deutsche Bank, Hong Kong and Shanghai Banking Corporation (HSBC), Bank of Tokyo berubah menjadi TokyoMitsibishi Bank dan Bangkok Bank. Sedangkan bank campuran adalah Bank campuran adalah PT Bank Perdania.

Disamping

melakukan sebagai bank umum, bank asing juga diberi kesempatan untuk menjalankan usaha bank pembangunan, akan tetapi hanya bank asing dalam bentuk bank campuran. Tempat usaha bagi bank umum asing dibatasi hanya di Jakarta sedangkan bank pembangunan asing dapat didirikan dan menjalankan usaha di Jakarta dan di tempattempat lain sepanjang ada kebutuhan yang nyata. Dalam menjalankan kegiatan usaha, bank asing dilarang menghimpun dana dalam bentuk tabungan. Kehadiran sepuluh kantor cabang bank asing tersebut kemudian diberikan jaminan penuh dalam komitmen pemerintah pada
WTO/GATS pada tahun 1998. Artinya kesepuluh kantor cabang bank asing tersebut diperbolehkan terus beroperasi dalam bentuk kantor cabang dan setiap perubahan kebijakan pemerintah tidak berakibat apapun bagi mereka.

Krisis keuangan global yang terjadi pada tahun 2007, telah mengangkat kembali perdebatan tentang kehadiran pihak asing dalam sektor perbankan. Hal ini antara lain dipicu pengalaman negara-negara di Eropa Tengah dan Timur. Pertanyaan yang mengemuka adalah apakah bank mentransmisikan kesulitan keuangannya dengan mengurangi kredit yang disalurkan ke nasabah kantor cabang atau nasabah perusahaan anak. Pengalama Eropa Tengah dan Timur pada awal krisis 2007-2008 menunjukan bahwa masalah keuangan yang dialami oleh kantor pusat suatu bank ditularkan secara cross border ke Eropa Tengan dan Timur. Akibatnya, perusahaan kesulitan memperoleh kredit dari bank asing yang kantor pusatnya mengalami kesulitan keuangan. Alasannya adalah bank enggan mengucurkan kredit kepada 
${ }^{1}$ Waliyunisa, ${ }^{2}$ Neni Sri Imaniyati, Kedudukan Bank Asing Dalam Perbankan Indonesia...

nasabahnya di lua negeri. Kondisi ini semacam ini dapat mengakibatkan votalitas dan instabilitas di negara tempat kantor cabang bank asing tersebut beroperasi. Pengalaman ini mengundang pertanyaan apakah kehadiran bank asing di suatu negara lebih baik dalam bentuk perusahaan anak.

(http://www.ejournal.umpwr.ac.id/in dex.php/segmen/article/view/25/84.p df).

\subsection{Ketentuan Mengenai Bank}

\section{Asing}

Berikut beberapa ketentuan mengenai bank asing (Puspita Sari Handayani, 2005). :

\section{a. Kantor Cabang Bank Asing} adalah kantor dari bank yang berkedudukan di luar negeri yang secara langsung atau tidak langsung bertanggung jawab kepada kantor pusat bank yang bersangkutan, dan mempunyai alamat serta tempat kedudukan di Indonesia; hal ini merupakan ketentuan mengenai Kantor Cabang Bank Asing berpedoman pada ketentuan tentang Persyaratan dan Tata Cara Pembukaan Kantor Cabang, Kantor Cabang Pembantu, dan Kantor Perwakilan dari Bank yang Berkedudukan di Luar Negeri.

b. Ketentuan mengenai Kantor Perwakilan Bank Asing berpedoman pada ketentuan tentang Persyaratan dan Tata Cara Pembukaan Kantor Cabang, Kantor Cabang Pembantu, dan Kantor Perwakilan dari Bank yang Berkedudukan di Luar Negeri yaitu: Kantor Perwakilan Bank Asing adalah kantor dari bank yang berkedudukan di luar negeri yang bertindak sematamata sebagai penghubung antara bank yang berkedudukan di luar negeri dengan nasabahnya.

c. Pemeriksaan terhadap Kantor Perwakilan Bank Asing ditujukan untuk memastikan kepatuhan Kantor Perwakilan Bank Asing terhadap ketentuan dan peraturan perundang-undangan lain yang berlaku. Yang dimaksud dengan ketentuan yang 
${ }^{1}$ Waliyunisa, ${ }^{2}$ Neni Sri Imaniyati, Kedudukan Bank Asing Dalam Perbankan Indonesia...

berlaku antara lain adalah ketentuan tentang Persyaratan dan Tata Cara Pembukaan Kantor Cabang, Kantor Cabang Pembantu, dan Kantor Perwakilan dari Bank Yang Berkedudukan Di Luar Negeri serta ketentuan tentang Sistem Informasi Debitur.

d. Bank, Kantor Perwakilan Bank Asing, dan pihak-pihak wajib segera memperlihatkan dan/atau memberikan kepada pemeriksa:

1) buku-buku, berkas-berkas, warkat, catatan, disposisi, memorandum, dokumen, data elektronis, termasuk salinan-salinannya;

2) segala keterangan dan penjelasan yang berkaitan dengan kegiatan usaha baik lisan maupun tertulis;

3) kesempatan penelitian keberadaan dan penggunaan sarana fisik yang berkaitan dengan kegiatan usaha;

4) hal-hal lain yang diperlukan dalam pemeriksaan dan wajib memberikan bantuan dalam rangka memperoleh kebenaran dari segala keterangan, dokumen dan penjelasan yang didapat pemeriksa, yang dimaksud dengan Bank, Kantor Perwakilan Bank Asing, dan pihak- pihak lain adalah termasuk dewan komisaris, direksi, pimpinan Kantor Cabang Bank Asing, pimpinan Kantor Perwakilan Bank Asing, dan pegawai yang langsung bertanggung jawab sehingga dilarang untuk menghambat proses pemeriksaan serta mempengaruhi pendapat, penilaian atau hasil dari tim pemeriksa.

\section{Tugas dan Macam-macam} Bank Asing

\subsection{Tugas Bank Asing}

Adapun kegiatan bank asing dan bank campuran di Indonesia adalah :

a. Dalam mencari dana bank asing dan bank campuran juga membuka simpanan. 
${ }^{1}$ Waliyunisa, ${ }^{2}$ Neni Sri Imaniyati, Kedudukan Bank Asing Dalam Perbankan Indonesia...

giro dan simpanan

deposito namun dilarang

menerima simpanan

dalam bentuk tabungan.

b. Dalam hal pemberian kredit yang diberikan lebih diarahkan ke bidang-bidang tertentu saja seperti dalam bidang

- Perdagangan

Internasional

- Bidang Industri dan

Produksi

- Penanaman Modal

Asing/Campuran

- Kredit yang tidak dapat dipenuhi oleh bank swasta nasional.

c. Sedangkan khusus untuk jasa-jasa bank lainnya juga dapat dilakukan oleh bank umum campuran dan asing sebagaimana layaknya bank umum yang ada di Indonesia seperti berikut ini :

- Jasa Transfer Jasa Miring

- Jasa Inkaso
- Jasa Jual Beli Valuta Asing

- Jasa Bank Card (kartu kredit)

- Jasa Bank Draft

- Jasa Safe Deposit Box

- Jasa Pembukaan dan Pembayaran L/C

- Jasa Bank Garansi

- Jasa Bank Notes

- Jasa Jual Beli Travellers Cheque

\subsection{Analisis kinerja Bank Pemerintah dan Bank Swasta Asing}

\begin{tabular}{|c|c|c|c|}
\hline \multicolumn{4}{|c|}{$\begin{array}{r}\text { Tabel 3.Perbandingan Kinerja Keuangan Ba } \\
\text { Asing dengan Bank Pemerintah }\end{array}$} \\
\hline Rasio & $\begin{array}{c}\text { Bank } \\
\text { Swasta } \\
\text { Asing } \\
\text { Rata- } \\
\text { Rata } \\
\text { Rasio } \\
\text { (dalam } \\
\% \text { ) }\end{array}$ & $\begin{array}{c}\text { Bank } \\
\text { Pemerintah }\end{array}$ & Keterangan \\
\hline \multicolumn{4}{|c|}{ Tahun 2017} \\
\hline ROA & 1,61 & 2,26 & $\begin{array}{l}\text { Lebih Bagus Bank } \\
\text { Pemerintah }\end{array}$ \\
\hline CAR & 18,42 & 15,95 & $\begin{array}{l}\text { Lebih Bagus Bank } \\
\text { Asing }\end{array}$ \\
\hline NIM & 6,08 & 5,83 & $\begin{array}{l}\text { Lebih Bagus Bank } \\
\text { Asing }\end{array}$ \\
\hline LDR & 67,97 & 67,85 & $\begin{array}{l}\text { Lebih Bagus Bank } \\
\text { Asing }\end{array}$ \\
\hline NPL & 13,54 & 13,4 & $\begin{array}{l}\text { Lebih Bagus Bank } \\
\text { Pemerintah }\end{array}$ \\
\hline
\end{tabular}


${ }^{1}$ Waliyunisa, ${ }^{2}$ Neni Sri Imaniyati, Kedudukan Bank Asing Dalam Perbankan Indonesia...

\begin{tabular}{|c|c|c|c|}
\hline \multicolumn{4}{|c|}{ Tahun 2018} \\
\hline ROA & 1,52 & 2,53 & $\begin{array}{l}\text { Lebih Bagus Bank } \\
\text { Pemerintah }\end{array}$ \\
\hline CAR & 19,92 & 15,68 & $\begin{array}{l}\text { Lebih Bagus Bank } \\
\text { Asing }\end{array}$ \\
\hline NIM & 5,77 & 5,47 & $\begin{array}{l}\text { Lebih Bagus Bank } \\
\text { Asing }\end{array}$ \\
\hline LDR & 63,9 & 66,79 & $\begin{array}{l}\text { Lebih Bagus Bank } \\
\text { Pemerintah }\end{array}$ \\
\hline NPL & 13,01 & 13 & $\begin{array}{l}\text { Lebih Bagus Bank } \\
\text { Pemerintah }\end{array}$ \\
\hline \multicolumn{4}{|c|}{ Tahun 2019} \\
\hline ROA & 1,67 & 3,03 & $\begin{array}{l}\text { Lebih Bagus Bank } \\
\text { Pemerintah }\end{array}$ \\
\hline CAR & 19,12 & 16,57 & $\begin{array}{l}\text { Lebih Bagus Bank } \\
\text { Asing }\end{array}$ \\
\hline NIM & 6,17 & 5,93 & $\begin{array}{l}\text { Lebih Bagus Bank } \\
\text { Asing }\end{array}$ \\
\hline LDR & 64,64 & 69,16 & $\begin{array}{l}\text { Lebih Bagus Bank } \\
\text { Pemerintah }\end{array}$ \\
\hline NPL & 15,97 & 13,56 & $\begin{array}{l}\text { Lebih Bagus Bank } \\
\text { Pemerintah }\end{array}$ \\
\hline
\end{tabular}

Berdasarkan data diatas menunjukkan bahwa dari kelima variabel pengukur kinerja terbukti ha-nya rasio return on assets (ROA) yang me-nunjukkan perbedaan nyata antara kinerja keuangan bank swasta nasional dengan kinerja keuangan bank pemerintah. Sedangkan capi-tal adequacy ratio (CAR), net interest mar-gin (NIM), loan to deposit ratio (LDR), non performing loans (NPL) tidak menunjukkanadanya perbedaan nyata kinerja keuangan bank swasta nasional dengan bank pemerintah. Return on assets (ROA) terpilih sebagai pembeda kinerja keuangan bank swasta na-sional dengan bank asing. Rata-rata return on assets (ROA) bank pemerintah lebih baik jika dibandingkan dengan rata-rata return on as-sets (ROA) bank swasta nasional. Bank pemerintah manajemennya dikelola secara lebih profesional dan melakukan efisiensi secara berkelanjutan sehingga keuntungan yang diperoleh lebih maksimal. (Ibid).

\subsection{Macam-macam Bank Asing}

\section{ABN AMRO Bank}

ABN AMRO dalah sebuah bank Belanda yang sejak tanggal 1 April 2010dimiliki sepenuhnya oleh Pemerintah Belanda. Entitas ABN AMRO Bank NV saat ini merupakan hasil pemisahan dari The Royal Bank of Scotland Group. Entitas sebelumnya yang bernama sama merupakan hasil merger pada tahun 19901991 antara Algemene Bank Nederland $(\mathrm{ABN}) \quad$ dan $\mathrm{De}$ Amsterdamsche-Rotterdamsche Bank (AMRO), yang sejarah awalnya bermula dari pendirian Nederlandsche HandelMaatschappij pada tahun 1824.

Pemerintah Belanda mengakuisisi Fortis Bank Nederland (Holding) NV, termasuk bagian 
kepemilikan pada RFS Holdings BV yang juga mencakup bagian bisnis ABN AMRO yang telah diakuisisi. Selanjutnya, pada tanggal 6 Februari 2010, bagian bisnis ABN AMRO yang dimiliki oleh Pemerintah Belanda dipisahkan dari bagian yang dimiliki oleh RBS. ABN AMRO Bank $\mathrm{NV}$, entitas lama yang mencakup bagian keduanya, diubah namanya menjadi The Royal Bank of Scotland NV, sementara bagian bisnis ABN AMRO milik Pemerintah Belanda diakuisisi oleh entitas baru yang menggunakan nama lama ABN AMRO Bank NV.

Pengalihan kepada ABN AMRO Group NV ini menandai selesainya proses pemisahan ABN AMRO dan RBS. Pada tanggal 15 April 2010, manajemen ABN AMRO Bank NV, Fortis Bank (Nederland) NV and ABN AMRO Group NV mengajukan proposal merger kepada Amsterdam Chamber of Commerce, di mana Fortis Bank (Nederland) NV akan menggabungkan diri ke dalam ABN AMRO Bank NV.

\section{Bank of America}

Bank of America Merrill Lynch adalah divisi korporat dan perbankan investasiBank of America. Bank ini menyediakan jasa penggabungan dan pengambilan alih, pasar modal saham dan obligasi, peminjaman modal, perdagangan saham, manajemen risiko, penelitian, dan manajemen likuiditas dan pembayaran. Bank ini dibentuk melalui kombinasi antara aktivitas perbankan investasi Bank of America dan Merrill Lynchsetelah diambil alih Bank of America pada Januari 2009. Bank of America Merrill Lynch memperoleh pendapatan tertinggi kedua dibandingkan bank investasi manapun pada tahun 2010, dengan pangsa pasar global 6,8 persen. Tahun 2010, bank ini memperoleh pendapatan tertinggi di antara bank-bank investasi di dunia menurut jumlah pinjaman terumpilkan dan sekuritas berlatar aset.

\section{Bank of Tokyo}

The Bank of Tokyo-Mitsubishi UFJ, Ltd. (BTMU; Kabushiki kaisha mitsubishi tōkyō yūefujei ginkō) merupakan bank terbesar di Jepang, yang didirikan pada 1 Januari 2006, dengan bergabungnya Bank of Tokyo-Mitsubishi Ltd. dan UFJ Bank Ltd. Bank ini merupakan bagian dari Mitsubishi UFJ Financial Group. Pada 31 Oktober 2010 BTMU mendapat peringkat oleh 
${ }^{1}$ Waliyunisa, ${ }^{2}$ Neni Sri Imaniyati, Kedudukan Bank Asing Dalam Perbankan Indonesia...

Bloomberg sebagai bank terbesar di Jepang dan terbesar ke-8 di dunia. Kantor pusat bank ini berlokasi di Marunouchi,Tokyo, Jepang.

\section{Bangkok Bank}

Bangkok Bank Public Company Limited (SET: BBL, bahasa

Thai: ธนาคารกรุงเทพ, RTGS: Thanakan Krung Thep), adalah bank komersial bermarkas di Bangkok, Thailand yang didirikan pada tahun 1944. Dengan lebih dari 18 juta akun, hal ini adalah bank terbesar di Thailand, dan bank daerah terbesar ketujuh di Asia Tenggara. Jaringan cabang mencakup lebih dari 1000 cabang di Thailand, dengan 25 cabang atau kantor perwakilan internasional di 13 negara, mencakup ASEAN dan negara-negara ekonomi utama, termasuk anak perusahaan yang sepenuhnya dimiliki di Malaysia dan Cina.

Bangkok Bank memiliki berbagai macam bisnis, perbankan investasi, dan layanan perbankan pribadi. Ini adalah salah satu pedagang global yang paling aktif baht Thailand dan obligasi bahtmata. Perdagangan bank semua mata uang utama serta sejumlah besar mata uang regional. Layanan lain termasuk transaksi yang sama hari dalam tagihan impor dan ekspor, ke dalam dan luar pengiriman uang, swap, opsi, dankontrak berjangka dan perdagangan di pasar primer dan sekunder untuk obligasi pemerintah dan surat hutang perusahaan.

Perusahaan menerima surat perintah kerajaan penunjukan untuk layanan dan telah memiliki hak istimewa untuk menampilkan royal garuda sejak tahun 1967. Bangkok Bank saat ini memiliki jaringan terbesar di luar negeri cabang, di 14 negara, dari bank manapun Thai, termasuk anak perusahaan yang sepenuhnya dimiliki di Malaysia, Cina, dan kantor perwakilan di Myanmar yang telah menjadi Myanmar Cabang pada 2 Juni $2015 \quad$ Bangkok Bank SWIFT kode BKKBTHBK.

\section{City Bank}

Citibank didirikanpada 1812 seba gai Bank Kota New York. Pada tahun 1894 menjadi bank terbesar di Amerika Serikat. Pada 1902 dia mulai mengadakan perluasan ke seluruh dunia dan menjadi bank pertama di AS yang memiliki departemen luar negeri. Pada 1930 dia menjadi bank terbesar di dunia dengan lebih dari 100 cabang di 23 negara. Dia mengubah namanya 
menjadi The First National City Bank of New Yorkpada 1955, dan kemudian menjadi First National City Bank pada 1962 dan menjadi Citibank pada 1976. Citibank adalah bank AS pertama yang memperkenalkan ATM di1970-an, dalam rangka pengurangan "teller" manusia dan memberikan akses akun 24jam.

Citibank sekarang ini adalah konsumen dan perusahaan bank dari jasa finansialraksasa Citigroup, perusahaan terbesar jenisnya di dunia. Citibank beroperasi di lebih dari 50 negara di dunia. Lebih dari setengah dari 1.400 kantornya berada di AS, kebanyakan di New York, New York, Chicago, Illinois, Miami, Florida, danWashington, DC, dan juga di California. Bank ini juga menawarkan

produk asuransi daninvestasi. Mereka menawarkan pelayanan online dan merupakan salah satu yang paling sukses, dengan sekitar 15 juta pengguna.

Citibank, N.A. (Citibank) merupakan cabang dari Citibank N.A yang berkantor pusat di New York, Amerika Serikat. Citibank, N.A sepenuhnya merupakan bagian dari
Citigroup,Inc. Citi sudah hadir di Indonesia sejak tahun 1968. Bersama dengan lebih dari 3.500 karyawan, Citi dengan bangga melayani Indonesia dengan menyediakan layanan perbankan harian, perusahaan dan investasi untuk para customernya.

\section{Standard Chartered Bank}

Standard Chartered Bank beraspirasi untuk menjadi bank internasional terbaik di dunia. Dengan dukungan lebih dari 75.000 karyawan yang terdiri atas 115 kebangsaan di lebih dari 70 negara, kami memiliki posisi solid untuk mencapai pertumbuhan melalui berbagai kesempatan di berbagai pasar terbaik dan penuh keragaman di dunia. Standard Chartered Bank memimpin dalam hal:
a. Perkembangan pasar yang dinamis ;
b. Produk dan layanan yang inovatif ;
c. Tim yang multikultural dan berprestasi ;
d. Strategi bisnis yang berkesinambungan.

$\begin{array}{clc}\text { Standard } & \text { Chartered } & \text { Bank } \\ \text { memiliki jaringan } & \text { internasional } & \text { yang }\end{array}$ 
meliputi lebih dari 1.700 cabang dan lebih dari 5.800 ATM yang tersebar di wilayah Asia, Afrika dan Timur Tengah. Kami hadir di lebih dari 70 negara di benua Asia Pasifik, Asia Tenggara, Timur Tengah, Afrika, Inggris Raya dan Amerika. Saat ini, Indonesia merupakan kontributor keenam terbesar dalam jaringan global Standard Chartered Bank. Sebagai salah satu bank tertua di Indonesia, Standard Chartered Bank telah hadir di Indonesia selama 150 tahun, sejak tahun 1863.

Pada saat ini Standard Chartered mempekerjakan lebih dari 2200 karyawan dan secara konsisten memberikan lebih dari 100 peluang kerja baru setiap tahunnya, selama 3 tahun terakhir. Selain itu, saat ini juga terdapat lebih dari 100 orang Indonesia yang berkarir di berbagai jaringan global Standard Chartered di seluruh dunia. Saat ini, Standard Chartered Bank merupakan salah satu dari 5 bank internasional terdepan dengan jejak geografis terbesar di Indonesia yang mencakup 27 kantor cabang di 8 kota dengan dukungan lebih dari 49.000 ATM Bersama.

Pada tahun 2006, bersama mitra strategis kami yaitu PT Astra
Internasional, kami menginvestasikan hampir USD200 juta dan mengakuisisi 89\% kepemilikan saham di Permata Bank, yang merupakan bank kedelapan terbesar di Indonesia . Keberhasilan ini memposisikan Standard Chartered Bank sebagai investor asal negara Inggris terbesar di industri perbankan Indonesia. Selain itu, melalui akuisisi yang dilakukan oleh Group Standard Chartered Bank atas American Express Bank pada awal tahun 2008, kini terdapat kesempatan besar untuk semakin memperluas layanan di pasar yang lebih spesifik, yaitu layanan Priority Banking. (http://www.fh.unsri.ac.id/userfiles/2\%2 0CBentuk\%20\&\%20Jenis\%20Bank.pdf, diakses pada tanggal 16 April 2020 pukul 14.58).

\section{MANAJEMEN DANA ASING BANK}

Manajemen Dana Asing Bank adalah mengatur penarikan dan penetapan sarana agar penabungan yang efektif agar pemilik uang (SSU) tertarik untuk menabungkan uangnya pada bank bersangkutan. Dana Asing Bank adalah sejumlah uang tabungan atau pinjaman yang diterima bank dari pihak ketiga dan harus dikembalikan bersama bunganya 
sesuai dengan perjanjian. (Bambang

Djinarto, 2000 : 11).

Dana Asing Bank ini sangat penting untuk operasi investasi sekunder suatu bank. Investasi sekunder diartikan investasi yang produktif dengan menyalurkan kredit kepada masyarakat. Pinjaman bank ini bersumber dari tabungan masyarakat melalui sarana rekening giro, deposito, buku tabungan, dan sebagainya. Pimpinan bank harus berusaha untuk mengumpulkan dana sebanyak-banyaknya agar bank dapat menyalurkan kredit yang banyak pula. Penyaluran kredit yang banyak ini memberikan peluang bagi bank untuk memperoleh laba yang menjadi tujuan didirikannnya bank.

Akan tetapi, pengumpulan dana asing ini memiliki banyak masalah, seperti cost of fund dan price credit agar spread profit yang diinginkan dapat tercapai. Penentuan besarnya cost of fund dan price of credit harus dapat bersaing dengan bank lain sehingga spread profit digunakan sebagai pedoman. (Shellagh Heffrena, 2005 :42).

Dana asing telah berasal dari sumber ekstren, berupa tabungan masyarakat, perusahaan, pemerintah, LKB dan LKBB antara lain :
1). Tabungan

Tabungan atau saving adalah pendapatan yang tidak dikonsumsi atau pendapatan dikurangi dengan konsumsi. Jika hasilnya positif berarti terdapat tabungan, tetapi apabila hasilnya nregatif maka terjadi disaving (terdapat utang).

\section{2). Simpanan}

Simpanan atau tabungan adalah dana yang dipercayakan masyarakat kepada bank dalam bentuk giro, deposito, berjangka, sertifikat deposito, tabungan dan bentuk lainnya yang dapat dipersamakan dengan itu (UndangUndang Republik Indonesia Nomor 7 Tahun 1992 tentang Perbankan Bab 1 Pasal 1 ayat 6).

\section{3). Idle Money}

Idle Money adalah uang kartal yang tidak dipergunakann untuk membayar transaksi karena disimpan oleh pemiliknya (seperti dalam dompet, boks, GWM, dan lain-lain). John Maynard Keynes dalam teori Liquidity Preference mengemukakan tiga motif terjadinya idle money tersebut. 
${ }^{1}$ Waliyunisa, ${ }^{2}$ Neni Sri Imaniyati, Kedudukan Bank Asing Dalam Perbankan Indonesia...

a. Motif Transaksi atau Transaction Motive dimana seseorang menyimpan uang tunai karena keperluan pembayaran transaksi sehari-hari yang akan dilakukannya.

b. Motif berjaga-jaga atau Preculative Motive dimana seseorang menyimpan uang tunai karena ingin berjaga-jaga atas hal yang akan terjadi pada amsa akan datang.

c. Motif Spekulasi atau Speculative Motive dimana seseorang menyimpan uang tunai karena menurut perhitungannya harga barang-barang akan turun atau tingkat suku bunga bank akan naik di masa yang akan datang.

\section{MACAM-MACAM SUMBER DANA ASING BANK}

Dana asing bank bersumber dari pihak ketiga yang diterima bank berupa pinjaman melalui sarana-sarana berikut :

\section{a. Rekening Giro}

Giro atau simpanan yang dapat dipergunakan sebagai alat pembayaran dan penarikannya dapat dilakukan setiap saat dengan menggunakan cek, sarana pemerintah pembayaran lainnya. b. Rekening Koran

Rekening koran adalah suatu sarana menabung dan pemberian kredit rekening koran oleh bank umum, saldonya bisa positif ataupun negatif dan dapat ditarik setiap saat dengan cek, bilyet giro, dan perintah pembayaran lainnya.

c. Tabungan-tabungan lainnya

Tabungan-tabungan lainnya merupakan sumber dana paling menguntungkan, karena bunganya relatif rendah dan adanya wajib saldo minimal.

d. Pinjaman LKB dan LKBB

Dana asing bank berasal dari pinjaman antar Lembaga Keuangan Bank dan Lembaga Keuangan Bukan Bank. Pinjaman dari LKB seperti Kredit Likuiditas Bank Indonesia, Bantuan Likuiditas Bank Indonesia dan Interball Call Money Market.

e. Otoritas Penagihan

Dana asing bank dapat diperoleh apabila suatu bank mendapat otoritas penagihan kepentingan dari suatu perusahaan atau lembaga.

f. Penjualan Surat-Surat Berharga Pasar Uang

Penerbitan dan penjualan suratsurat berharga merupakan sumber dana bagi suatu bank, misalnya cek perjalanan 
${ }^{1}$ Waliyunisa, ${ }^{2}$ Neni Sri Imaniyati, Kedudukan Bank Asing Dalam Perbankan Indonesia...

(traveller cheque), Letter of Credit, dan Obligasi

g. Sumber-sumber lain ini berasal dari pelaksanaan lalu lintas pembayaran seperti wesel cek dan bank garansi yang jaminannya diberikan kontraktor berupa uang tunai, hibah. Sumbangan.

\section{PENUTUP}

\section{Kesimpulan}

(1) Pada awalnya, bank-bank asing hanya boleh beroperasi di DKI Jakarta saja. Namun setelah dikeluarkan Pakto 27, 1988, bank-bank swasta asing ini diperkenankan untuk membuka kantor cabang pembantu di delapan kota, yaitu Jakarta, Surabaya, Semarang, Bandung, Denpasar, Ujung Pandang (Makasar), Medan, dan Batam. Tugas dan fungsinya telah ditentukan secara tegas di dalam pemberian izinnya oleh menteri keuangan dan bank asing ini hanya berada dikota-kota besar saja. Untuk mengkoordinasikan kehidupan perbankan di indonesia antara lain di dalam menyediakan dana uang untuk operasi dan mengatur serta mengelola peredaran uang di masyarakat, diperlukan suatu bank khusus yang disebut bank sirkulasi atau bank sentral.
Dibukanya kesempatan bank asing dan bank campuran untuk beroperasi di Indonesia terkait dengan kebutuhan akan modal asing.

(2) Kepemilikan bank asing terhadap perbankan nasional semakin meningkat diharapkan bank asing tetap dapat membantu misi pemerintah untuk mendorong pembangunan di Indonesia dalam rangka mencapai pertumbuhan, pemerataan dan stabilitas yang merupakan tujuan perbankan di Indonesia sebagaimana diatur oleh Pasal 4 Undang-Undang Nomor 7 Tahun 1992, sebagaimana telah diubah dengan Undang-Undang Nomor 10 Tahun 1998.

\section{Saran}

(1) Masuknya Bank Asink diharapkan dapat mendorong perkembangan perbankan serta perekonomian nasional. Secara umum, keuntungan yang diperoleh dengan masuknya bank-bank asing, termasuk bank campuran, antara lain adalah sebagai saluran capital inflows untuk ekonomi domestik, meningkatkan kompetisi antar bank, dan memperkenalkan produk-produk yang lebih bervariasi.

(2)Harus adanya pengawasan dan pembinaan yang efektif terhadap 
${ }^{1}$ Waliyunisa, ${ }^{2}$ Neni Sri Imaniyati, Kedudukan Bank Asing Dalam Perbankan Indonesia...

bank asing. Disamping itu permasalahan bank asing perlu diatur kembali secara menyeluruh sehingga lebih menimbulkan keadilan dan kepastian hukum bagi semua pihak.

\section{DAFTAR PUSTAKA}

\section{A. Buku}

Djinarto, Bambang, Banking Asset

Liability Management :

Perencanaan, Strategi,

Pengawasan dan

Pengelolaan Dana,

Jakarta : PT.Gramedia

Pustaka Utama, 2000.

Handayani, Puspita Sari. Analisis

Perbandingan

Kinerja Bank

Nasional, Bank

Campuran Dan Bank

Asing Dengan

Menggunakan Rasio

Keuangan. Diss.

Program Pasca

Sarjana Universitas

Diponegoro, 2005.

Hasibuan, Malayu S.P, Dasar-Dasar perbankan, PT Bumi Aksara, Jakarta, 2005.
Kasmir, Dasar-Dasar Perbankan, Rajawali Pers, Jakarta, 2012.

Henry, Tan. ANALISIS PERBEDAAN KINERJA KEUANGAN ANTARA BANK ASING DAN BANK UMUM DI INDONESIA. Magister Manajemen / Perbankan. Universitas Gunadarma, Indonesia.

Shellagh Heffrena, Modern Banking, John Wiley and Son 1tf, West Sussex, England, 2005.

\section{B. Peraturan Perundang-Undangan Undang-Undang Nomor 10 Tahun 1998 Tentang Perbankan}

\section{Internet}

http://www.ejournal.umpwr.ac.id/inde x.php/segmen/article/view/25 /84.pdf , diakses pada tanggal 17 April 2020 pukul 19.30 http://www.fh.unsri.ac.id/userfile s/2\%20CBentuk\%20\&\%20Jenis \%20Bank.pdf, diakses pada tanggal 16 April 2020 pukul 14.58 